\title{
Hemodynamic effects of volume replacement with saline solution and hypertonic hydroxyethyl starch in $\operatorname{dogs}{ }^{1}$
}

\author{
Efeitos hemodinâmicos da reposição volêmica com solução salina e hidroxi-etil amido \\ hipertônico em cães
}

\author{
Artur Udelsmann', Matheus Rodrigues Bonfim" ${ }^{I I}$, William Adalberto Silva ${ }^{I I}$, Ana Cristina de Moraes ${ }^{\text {II }}$ \\ ${ }^{1}$ Associate Professor, Department of Anesthesiology and Laboratory of Experimental Anesthesia, School of Medicine, UNICAMP, Sao Paulo, Brazil. \\ II Fellow Master degree, Department of Surgery, School of Medicine, UNICAMP, Sao Paulo, Brazil.

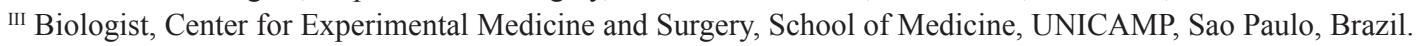

\begin{abstract}
Purpose: To investigate hemodynamic response to volume replacement with saline solution and hypertonic hydroxyethyl starch in hypovolemic dogs. Methods: Forty dogs under general anesthesia and hemodynamic monitoring, following measurements at baseline, were bled $20 \mathrm{ml} . \mathrm{Kg}^{-1}$ and parameters were measured again after 10 minutes. The animals were randomly divided in two groups and volume replacement was performed with saline solution twice the volume removed or $4 \mathrm{ml} \mathrm{Kg}^{-1}$ of hypertonic hydroxyethyl starch. Hemodynamic data were again measured after 5, 15, 30, 45 and 60 minutes. Results: With both solutions values returned to satisfactory hemodynamic levels. With saline solution, there was a greater amplitude in variations that tended to decrease progressively. With hypertonic hydroxyethyl starch, the parameters studied returned more rapidly to levels similar to those at baseline and varied less. Conclusion: Both solutions proved to be efficient at replacing volume in the short period studied, although hypertonic hydroxyethyl starch produced more stable results.
\end{abstract}

Key words: Hemodynamics. Hypovolemia. Hetastarch. Saline Solution, Hypertonic. Dogs.

\section{RESUMO}

Objetivo: Avaliar em cães hipovolêmicos as respostas hemodinâmicas da reposição volêmica com solução salina e hidroxi-etil amido hipertônico. Métodos: Quarenta cães sob anestesia geral e monitorização hemodinâmica, após medidas em repouso foram sangrados 20 ml. $\mathrm{Kg}^{-1}$ e tiveram os parâmetros novamente medidos após 10 minutos. Os animais foram aleatoriamente divididos em dois grupos nos quais foi realizada reposição volêmica com solução fisiológica duas vezes o volume retirado ou $4 \mathrm{ml} \mathrm{Kg}^{-1}$ de hidroxi-etil amido hipertônico e os dados hemodinâmicos medidos novamente após 5, 15, 30, 45 e 60 minutos. Resultados: A reposição volêmica com as duas soluções fez os valores retornarem a níveis hemodinâmicos satisfatórios, a amplitude das variações com solução fisiológica foi maior, mas tendeu a diminuir progressivamente, com o hidroxi-etil amido hipertônico os parâmetros estudados retornaram a semelhantes ao repouso mais rapidamente e variaram menos. Conclusão: Ambas soluções se mostraram eficientes na reposição volêmica, o hidroxi-etil amido hipertônico proporcionou resultados mais estáveis.

Descritores: Hemodinâmica. Hipovolemia. Hetamido. Solução Salina Hipertônica. Cães.

${ }^{1}$ Research performed at the Laboratory of Experimental Anesthesia, School of Medicine, State University of Campinas (UNICAMP), Sao Paulo, Brazil.

\section{Introduction}

In recent years, trauma with severe blood loss has become the leading cause of death in young people. Early diagnosis, identification of the cause and rapid treatment are important for the reduction in morbidity and mortality ${ }^{1}$. Perioperative accidents may also put the surgical patient at risk of developing severe hypovolemia. Blood volume is a crucial factor in the maintenance of hemodynamic balance and tissue oxygenation. Correction of intravascular volume deficit is aimed at improving myocardial performance, increasing end-diastolic volume and optimizing oxygen transportation. In most cases, it is difficult to determine the volume of blood lost and blood loss is frequently underestimated. Shock occurs when there is vital organ hypoperfusion and signs may vary according to the amount of volume lost $\mathrm{t}^{2}$. Blood loss of 10 to $15 \%$ of the blood volume is associated with clinical signs that are easily controlled by the organism. The loss of 20 to $35 \%$ is associated with the clinical syndrome of hypovolemic shock, while loss of $40 \%$ or more may be fatal. In hemorrhagic shock, an acute reduction in blood volume causes the sympathetic branch of the autonomic nervous system to compensate by generating peripheral vasoconstriction, tachychardia and increased myocardial contractility. This increases oxygen demand to levels that cannot be maintained indefinitely. Simultaneously, tissue hypoperfusion 
generates anaerobic metabolism resulting in tissue hypoxia, acidosis and the release of various mediators that trigger a systemic inflammatory response ${ }^{2}$. There are various options for fluid replacement. In addition to crystalloids, such as saline and Ringer solutions, there are nonprotein colloid solutions and hypertonic solutions. The solution to be infused into a hemodynamically unstable patient is still under debate. Crystalloid solution is recommended as the first solution of choice, although both colloids and crystalloid have advantages and disadvantages ${ }^{2,3}$. The main advantages of crystalloid solutions are their frequent use, greater safety and low cost. The major disadvantage of crystalloid solution is its rapid movement from the intravascular to the extravascular space requiring fluid infusion in considerably larger amounts than the volume lost for adequate resuscitation ${ }^{4,5}$. Colloids, due to their high molecular weight remain a longer time in the intravascular space, producing more hemodynamic stability. However, the cost of these solutions is high and there is a potential risk of allergic reactions and blood dyscrasia ${ }^{2}$. The use of small-volume hypertonic solutions for ressuscitation has proved to be an interesting alternative in experimental models of hemorrhagic shock $^{6}$. Pioneer studies conducted in Brazil in the eighties have revealed that the infusion of small volumes of $7.5 \% \mathrm{NaCl}$ solution produces rapid restoration of hemodynamic parameters and thus less demand for blood transfusions ${ }^{7}$. Subsequently, it was demonstrated that the addition of a hypertonic solution could increase and prolong the beneficial effects of a hyperoncotic solution $^{8}$. Hydroxyethyl starch is a natural modified polymer, structurally very similar to glycogen, with volume expansion properties. There are different types of hydroxyethyl starch and their properties are defined by the molecular physical-chemical characteristics of each product. Hypertonic hydroxyethyl starch solution is a combination of this colloid with $7.2 \% \mathrm{NaCl}$ allowing small-volume fluid replacement. The aim of this study was to compare the hemodynamic response after volume replacement with saline and hypertonic hydroxyethyl starch in dogs submitted to hypovolemia by artificial hemorrhage.

\section{Methods}

After approval by the Animal Experimentation Ethics Committee of the Biology Institute at UNICAMP, 40 male and female mongrel dogs were used and follow the Council for International Organization of Medical Sciences ethical code for animal experimentation and the principles of the Brazilian College on Animal Experimentation. The animals were in good health according to a veterinary clinical examination and were randomly divided into two groups of 20 animals: the SS group (saline solution) and the HHS group (hypertonic hydroxyethyl starch). At first, the animals were weighed, and body surface area (BSA) was estimated according to a classical formula in the literature ${ }^{9}$ for calculation of hemodynamic indexes. After blood cannulation in the fore limb, the induction of anesthesia was performed with 18 mg. $\mathrm{Kg}^{-1}$ sodium thiopental ${ }^{10}$. The animals were positioned on a surgical stainless steel trough and intubated. Anesthesia was maintained with isoflurane in $\mathrm{O}_{2}$ at a concentration of 1.0 MAC $(1.3 \% \text { end-tidal })^{11}$, under controlled mechanical ventilation with a tidal volume of $15 \mathrm{ml} . \mathrm{Kg}^{-1}$. Respiratory rate was adjusted to obtain $\mathrm{ETCO}_{2}$ between 32 and $34 \mathrm{mmHg}$. An electrocardioscope was placed in the DII lead and pulse oximetry was measured by placing the sensor on the animal tongue. In the medial left hind limb of the animal, dissection and cannulation of the femoral artery was performed for continuous arterial pressure measurement. A Swan-Ganz cathether was inserted into the femoral vein and hemodynamic measurements were made by the Datex Engstron AS/3 multiparametric monitor. Simultaneously, a blood sample was drawn for hematocrit and hemoglobin measurement. In the opposite limb, dissection and cannulation of the femoral vein was performed for subsequent bleeding. The hemodynamic variables measured were: mean arterial pressure (MAP), heart rate (HR), central venous pressure (CVP), mean pulmonary artery pressure (MPAP), pulmonary capillary wedge pressure (PCWP). The cardiac index (CI), stroke index (SI), systemic vascular resistance index (SVRI), pulmonary vascular resistance index (PVRI), left ventricular stroke work index (LVSWI) and right ventricular stroke work index (RVSWI) were calculated. After monitoring the animals, were waited 30 minutes for hemodynamic stability. The first hemodynamic measurements were then made at baseline (M1). Immediately after, bleeding of $20 \mathrm{ml} . \mathrm{Kg}^{-1}$ during 10 minutes was performed to produce hypovolemia. Ten minutes after new hemodynamic measurements were obtained (M2). Subsequently, volume replacement was performed with saline solution at a ratio of twice the blood volume removed or with hypertonic hydroxyethyl starch at a dose of $4 \mathrm{ml} . \mathrm{Kg}^{-1}$ of body weight. New hemodynamic measurements were performed after 5, 15, 30, 45 and 60 minutes, corresponding to M3 to M7, respectively. At the end of the study, the animals were sacrificed under anesthesia with an intravenous injection of $10 \mathrm{ml}$ of $19.1 \%$ potassium chloride solution. Data were analyzed and compared statistically. To compare categorical variables, the chi-square test was used. For the comparison of numerical continuous variables at a single moment, a Student's t-test was used. To compare numerical variables between both groups and between time periods, analysis of variance (ANOVA) for repeated measures was used. Also used were the Tukey test for multiple comparisons to compare groups at each time period and the contrast profile test to analyze time progression in each group. The significance level adopted was $5 \%$, i.e., $\mathrm{p}<0.05$.

\section{Results}

Table 1 shows group distribution by sex, body weight, body surface area, hematocrit and hemoglobin before bleeding. There were no significant differences between groups.

\section{TABLE 1}

\begin{tabular}{lcc}
\hline \multicolumn{1}{c}{ Group } & SS & HHS \\
\hline male & 14 & 15 \\
female & 6 & 5 \\
weigh $(\mathrm{Kg})$ & $18.08 \pm 5,31$ & $17.78 \pm 3.55$ \\
$\mathrm{BSA}\left(\mathrm{m}^{2}\right)$ & $0.72 \pm 0,14$ & $0.71 \pm 0.09$ \\
$\mathrm{Ht}(\%)$ & $29.67 \pm 4.77$ & $28.80 \pm 6.72$ \\
$\mathrm{Hb}(\mathrm{g} \%)$ & $9.75 \pm 1,7$ & $9.55 \pm 2.27$ \\
\hline
\end{tabular}


All hemodynamic parameters measured at baseline (M1) were statistically similar in both groups as well as immediately after bleeding (M2).

Table 2 shows there was no difference in mean arterial blood pressure between the groups $(p=0.242)$. A significant decrease was observed after bleeding. With volume replacement, values were comparable to those at baseline after M5 $(\mathrm{p}<0.001)$.

TABLE 2 - Mean arterial blood pressure \pm SD $(\mathrm{mmHg})$

\begin{tabular}{ccc}
\hline Groups & SS & HHS \\
\hline M1 & $99.2 \pm 20.49$ & $100.2 \pm 18.47$ \\
M2 & $65.75 \pm 23.73$ & $63.8 \pm 26.56$ \\
M3 & $96.55 \pm 18.26$ & $78.45 \pm 20.11$ \\
M4 & $94.85 \pm 19.2$ & $84.30 \pm 18.24$ \\
M5 & $97.6 \pm 21.97$ & $91.1 \pm 17.57$ \\
M6 & $98.65 \pm 21.73$ & $92.6 \pm 17.58$ \\
M7 & $102,3 \pm 20,91$ & $95,40 \pm 17,21$ \\
\hline
\end{tabular}

Table 3 shows there was no difference in heart rate between the groups $(p=0.737)$. No variation was observed immediately after bleeding. After M4, there was a similar increase in both groups that persisted until the end of the experiment $(\mathrm{p}<0.001)$.

TABLE 3 - Heart rate \pm SD (beats. min $^{-1}$ )

\begin{tabular}{ccc}
\hline Groups & SS & HHS \\
\hline M1 & $125.3 \pm 24$ & $126.4 \pm 23.2$ \\
M2 & $131.3 \pm 29.63$ & $121.8 \pm 26.25$ \\
M3 & $122.4 \pm 17.06$ & $125 \pm 18.86$ \\
M4 & $131.4 \pm 19.24$ & $133.5 \pm 18.27$ \\
M5 & $134.9 \pm 20.94$ & $140.7 \pm 15.89$ \\
M6 & $137.4 \pm 16.93$ & $143 \pm 15.66$ \\
M7 & $139.2 \pm 16.76$ & $144.6 \pm 16.3$ \\
\hline
\end{tabular}

Table 4 shows that after bleeding, there was a significant but similar decrease in of cardiac index in both groups. Volume replacement increased values to levels exceeding those at baseline starting at M3. These values persisted until the end of the experiment $(p<0.001)$. SS values exceeded HHS values from M3 to $\mathrm{M} 7(\mathrm{p}<0.001)$.

TABLE 4 - Cardiac index \pm SD $\left(1 \cdot \mathrm{min}^{-1} \cdot \mathrm{m}^{2}\right)$

\begin{tabular}{ccc}
\hline Groups & SS & HHS \\
\hline M1 & $2.7 \pm 0.5$ & $2.6 \pm 0.8$ \\
M2 & $1.52 \pm 0.34$ & $1.39 \pm 0.5$ \\
M3 & $4.32 \pm 0.59$ & $2.93 \pm 0.74$ \\
M4 & $4.28 \pm 0.64$ & $2.88 \pm 0.76$ \\
M5 & $3.89 \pm 0.77$ & $2.96 \pm 0.68$ \\
M6 & $3.69 \pm 0.8$ & $2.93 \pm 0.67$ \\
M7 & $3.5 \pm 0.77$ & $2.94 \pm 0.72$ \\
\hline
\end{tabular}

Table 5 shows that after bleeding there was a central venous pressure decrease in both groups but only in the SS group it was significant $(\mathrm{p}<0.001)$. After volume replacement, values remained similar to those at baseline until M7 in the HHS group. In the SS group, there was an increase in M3 and M4 and they returned to similar to those at baseline starting at M5 $(\mathrm{p}<0.001))$. At M3, SS group was greater than HHS ( $\mathrm{p}=0.012$ ).

TABLE 5 - Central venous pressure $\pm \mathrm{SD}\left(\mathrm{cmH}_{2} \mathrm{O}\right)$

\begin{tabular}{ccc}
\hline Groups & SS & HHS \\
\hline M1 & $6.1 \pm 1.48$ & $6.2 \pm 1.54$ \\
M2 & $5.1 \pm 1.94$ & $5.4 \pm 1.73$ \\
M3 & $7.8 \pm 1.88$ & $6.4 \pm 1.67$ \\
M4 & $7.15 \pm 1.93$ & $6.4 \pm 1.76$ \\
M5 & $6.8 \pm 2.46$ & $6.15 \pm 0.99$ \\
M6 & $6.5 \pm 2.44$ & $6.05 \pm 1.15$ \\
M7 & $6.3 \pm 2.62$ & $6.1 \pm 1.33$ \\
\hline
\end{tabular}


Table 6 shows the results of mean pulmonary artery pressure. There were no differences between the groups $(\mathrm{p}=0.843)$. After bleeding, a significant decrease occurred in both groups. With volume replacement, values exceeding baseline values were obtained in M3 returning to near baseline levels in M4 $(\mathrm{p}<0.001)$.

TABLE 6 - Mean pulmonary arterial pressure \pm SD $(\mathrm{mmHg})$

\begin{tabular}{ccc}
\hline Groups & SS & HHS \\
\hline M1 & $13.55 \pm 2.7$ & $14.3 \pm 3.33$ \\
M2 & $11.2 \pm 2.75$ & $11.9 \pm 3.01$ \\
M3 & $15.25 \pm 3.52$ & $14.3 \pm 3.61$ \\
M4 & $14.45 \pm 3.43$ & $13.8 \pm 3.09$ \\
M5 & $14.25 \pm 4.02$ & $14.25 \pm 2.63$ \\
M6 & $13.85 \pm 3.75$ & $14.3 \pm 2.75$ \\
M7 & $14.35 \pm 3.08$ & $14.65 \pm 3.65$ \\
\hline
\end{tabular}

Table 7 shows that after bleeding there was a decrease in pulmonary capillary wedge pressure in both groups. With volume replacement, these values increased in the SS group exceeding those at baseline in M3 and M4. In contrast, in the HHS group values were lower than those at baseline in M4 and M7 $(p<0.001)$. In M3, SS values exceeded HHS values $(p<0.001)$.

TABLE 7 - Pulmonary capillary wedge pressure \pm SD (mmHg)

\begin{tabular}{ccc}
\hline Groups & SS & HHS \\
\hline M1 & $6.25 \pm 2.12$ & $7.1 \pm 1.89$ \\
M2 & $4.9 \pm 2.77$ & $5.4 \pm 2.09$ \\
M3 & $9.1 \pm 3.04$ & $6.45 \pm 2.24$ \\
M4 & $7.85 \pm 3.07$ & $6.4 \pm 2.21$ \\
M5 & $7.05 \pm 3.53$ & $6.4 \pm 1.6$ \\
M6 & $6.45 \pm 3.43$ & $6.5 \pm 1.96$ \\
M7 & $6.4 \pm 3.27$ & $6.2 \pm 2.5$ \\
\hline
\end{tabular}

Table 8 shows that there was a similar reduction of stroke volume in both groups after bleeding. With volume replacement, values increased to levels higher than those at baseline. However, in the SS group values even at M4 returned to near M1 values. In the SS group these values were maintained significantly higher until M6 $(p<0.001)$. SS values exceeded HHS values from M3 to M6 $(\mathrm{P}<0.001)$.

TABLE 8 - Stroke index \pm SD $\left(\mathrm{ml} \cdot\right.$ beat $\left.^{-1} \cdot \mathrm{m}^{2}\right)$

\begin{tabular}{ccc}
\hline Groups & SS & HHS \\
\hline M1 & $21.75 \pm 5.18$ & $20.2 \pm 5.97$ \\
M2 & $11.55 \pm 3.39$ & $11 \pm 4$ \\
M3 & $35.25 \pm 6.02$ & $23.15 \pm 6.29$ \\
M4 & $32.7 \pm 6.32$ & $21.25 \pm 6.07$ \\
M5 & $28.45 \pm 5.37$ & $20.8 \pm 5.6$ \\
M6 & $26.4 \pm 5.93$ & $20.3 \pm 5.63$ \\
M7 & $24.85 \pm 5.56$ & $20.05 \pm 5.82$ \\
\hline
\end{tabular}

Table 9 shows there was no change in systemic vascular resistance index after bleeding. With volume replacement, values decreased significantly and remained lower than those at baseline until the end of the experiment in both groups $(\mathrm{p}<0.001)$. This decrease was more important in the SS group from M3 to M6 $(\mathrm{p}=0.018)$.

TABLE 9 - Systemic vascular resistance index $\pm \mathrm{SD}\left(\right.$ dynes. $\left.\mathrm{seg}^{-1} \cdot \mathrm{cm}^{5} \cdot \mathrm{m}^{-2}\right)$

\begin{tabular}{ccc}
\hline Groups & SS & HHS \\
\hline M1 & $2850 \pm 796.6$ & $3122 \pm 938.9$ \\
M2 & $3187 \pm 1021$ & $3489 \pm 1481$ \\
M3 & $1665 \pm 378.3$ & $2059 \pm 752.8$ \\
M4 & $1659 \pm 351.7$ & $2290 \pm 821.2$ \\
M5 & $1874 \pm 343.9$ & $2414 \pm 777.3$ \\
M6 & $2021 \pm 412.5$ & $2516 \pm 860$ \\
M7 & $2227 \pm 520.1$ & $2585 \pm 870.4$ \\
\hline
\end{tabular}


Table 10 shows the pulmonary vascular resistance index increased in both groups after bleeding and decreased after volume replacement. In the SS group, values remained lower than those at baseline until M6 but in the HHS group this occurred only in M4 $(p<0.001)$. In the SS group, there was a more important decrease with significantly lower values from M3 to M6 ( $<<0.001)$.

TABLE 10 - Pulmonary vascular resistance index $\pm \mathrm{SD}\left(\right.$ dynes. $\left.\mathrm{seg}^{-1} \cdot \mathrm{cm}^{5} \cdot \mathrm{m}^{-2}\right)$

\begin{tabular}{ccc}
\hline Groups & SS & HHS \\
\hline M1 & $228.2 \pm 73.12$ & $230.6 \pm 60.74$ \\
M2 & $350.1 \pm 133.8$ & $426.7 \pm 224.8$ \\
M3 & $118.9 \pm 38.92$ & $224.4 \pm 68.33$ \\
M4 & $126 \pm 37.13$ & $212.5 \pm 61.79$ \\
M5 & $162.7 \pm 56.16$ & $221.7 \pm 59.31$ \\
M6 & $183.9 \pm 108.6$ & $225.1 \pm 65.88$ \\
M7 & $203.8 \pm 124.6$ & $248.3 \pm 76.35$ \\
\hline
\end{tabular}

Table 11 shows the left ventricular stroke work index decreased significantly in both groups with bleeding. After volume replacement, HHS values returned to near baseline levels in M3, and were maintained until M7. In contrast, SS values increased significantly from M3 to M5 $(\mathrm{p}<0.001)$. SS values exceeded HHS values from M3 to M6 ( $p=0.005)$.

TABLE 11 - Left ventricular stroke work index $\pm \mathrm{SD}\left(\mathrm{g} \cdot \mathrm{min}^{-1} \cdot \mathrm{m}^{2}\right)$

\begin{tabular}{ccc}
\hline Groups & sS & HHS \\
\hline M1 & $27.07 \pm 7.25$ & $25.51 \pm 9.24$ \\
M2 & $9.59 \pm 4.73$ & $9.03 \pm 5.17$ \\
M3 & $41.37 \pm 8.98$ & $22.82 \pm 9.34$ \\
M4 & $38.72 \pm 9.86$ & $22.43 \pm 8.19$ \\
M5 & $35.58 \pm 11.24$ & $23.93 \pm 8.04$ \\
M6 & $33.7 \pm 10.55$ & $23.56 \pm 7.77$ \\
M7 & $32.91 \pm 10.09$ & $24.06 \pm 7.78$ \\
\hline
\end{tabular}

Table 12 shows the right ventricular stroke work index in the HHS group, only M2 value was significantly lower from baseline value. In contrast, there was an initial decrease in the SS group followed by an increase in all values that remained statistically different from baseline values until the end of the experiment $(p<0.001)$. SS values exceeded HHS values in M3 and M4 $(\mathrm{p}<0.001)$.

TABLE 12 - Right ventricular stroke work index $\pm \mathrm{SD}\left(\mathrm{g} \cdot \mathrm{min}^{-1} \cdot \mathrm{m}^{2}\right)$

\begin{tabular}{ccc}
\hline Groups & SS & HHS \\
\hline M1 & $2.18 \pm 0.69$ & $2.27 \pm 1.14$ \\
M2 & $0.94 \pm 0.42$ & $1 \pm 0.63$ \\
M3 & $3.58 \pm 1.21$ & $2.57 \pm 1.44$ \\
M4 & $3.26 \pm 1.15$ & $2.19 \pm 1.22$ \\
M5 & $2.99 \pm 1.25$ & $2.34 \pm 1.18$ \\
M6 & $2.78 \pm 1.14$ & $2.31 \pm 1.09$ \\
M7 & $2.8 \pm 0.94$ & $2.44 \pm 1.34$ \\
\hline
\end{tabular}

\section{Discussion}

In the model of hypovolemia studied, hemodynamic results were evaluated in dogs after the infusion of two volume replacement solutions with different mechanisms of action, simulating the initial treatment in trauma and hypovolemic patients. It was observed that both solutions provided a significant improvement in hemodynamics. Early replacement with large volumes of saline resulted in greater amplitude in variation. In the end of the experiment, there was a tendency for the amplitude to decrease. It was likely due to the passage of saline into the interstitial space. It is well-known that crystalloid solutions are not the best option for volume expansion, since one-fifth of the non-excreted volume remains in the plasma after equilibrium and demands the infusion of large volumes ${ }^{12}$ at least 2 to 3 times the estimated volume lost. In addition, studies have demonstrated that after 120 minutes even this volume is no longer in the intravascular space ${ }^{13}$. With hypertonic hydroxyethyl starch, the values studied returned to baseline (before blood loss) in a more stable manner. With the combination of a macromolecule and hypertonic $\mathrm{NaCl}$, molecules remain a longer time in the intravascular space, increasing colloid osmotic pressure and plasma volume. Fluid is absorved from the interstitial intracellular space allowing for a more lasting restoration of blood volume $e^{6,14}$. This study showed short-term results of volume replacement using two different solutions in hypovolemia. Response to fluid therapy may be different in the medium-term and long-term. Furthermore, in cases of severe hypovolemia, other therapies may become necessary. 


\section{Conclusion}

Both solutions proved to be efficient at replacing volume in the short period studied, although hypertonic hydroxyethyl starch produced more stable results.

\section{References}

1. Meletti JFA, Módolo NSP. Hemorrhagic shock hemodynamic and metabolic behavior: experimental study in dogs. Rev Bras Anestesiol. 2003;53:623-32.

2. Martel MJ, Arsenault MY, Bartellas E. Hemorrhagic shock. J Obstet Gynaecol Can. 2002;24:504-11.

3. Wade CE, Kramer GC, Grady JJ, Fabian TC. Efficacy of hypertonic $7,5 \%$ saline and $6 \%$ dextran-70 in treating trauma: A meta-analysis of controlled clinical studies. Surgery. 1997;122:609-16.

4. Shafi S, Kauder DR. Fluid resuscitation and blood replacement in patients with polytrauma. Clin Orthop Relat Res. 2004;422:37-42.

5. Moore F, McKinley BA, Moore EE. The next generation in shock resuscitation. Lancet. 2004;363:1988-96.

6. Sirieix D, Hongnat JM, Delayance S, D'Attellis N, Vicaut E, Bérrébi A, Paris M, Fabiani JN, Carpentier A, Baron JF. Comparison of the acute hemodinamic effects of hypertonic or colloid infusions immediately after mitral valve repair. Crit Care Med. 1999;27:2159-65.
7. Velasco IT, Pontieri V, Rocha e Silva Jr. M, Lopes OU. Hyperosmotic $\mathrm{NaCl}$ and severe hemorrhagic shock. Am J Physiol. 1980;239:664-73.

8. Mauritz W, Schimetta W, Oberreither S, Pölz W. Are hypertonic hyperoncotic solutions safe for prehospital small-volume resuscitation? Results of a prospective observational study. Eur J Emerg Med. 2002;9:315-9.

9. Holt JP, Rhode EA, Kines H. Ventricular volumes and body weight in mammals. Am J Physiol. 1968;215:704-15.

10. Hofmeister EH, Williams CO, Braun C, Moore PA. Propofol versus thiopental: effects on peri-induction intraocular pressures in normal dogs. Vet Anaesth Analg. 2008;35:275-81.

11. Hofmeister EH, Brainard BM, Sams LM, Allman DA, Cruse AM. Evaluation of induction characteristics and hypnotic potency of isoflurane and sevoflurane in healthy dogs. Am J Vet Res. 2008;69:451-6.

12. Svensen C, Hahn RG. Volume kinetics of Ringer solution, dextran 70 and hypertonic saline in male volunteers. Anesthesiology. 1997;87:204-12.

13. Nascimento Jr. P, Paiva Filho O, Carvalho LR, Braz JRC. Early hemodynamic and renal effects of hemorragic shock resuscitation with lactated ringer's solution, hydroxyethyl starch and hypertonic saline with or without 6\% Dextran-70. J Surg Res. 2006;136:98-105.

14. Kreimeier U, Messmer K. Small volume ressuscitation: from experimental evidence to clinical routine. Advantages and disadvantages of hypertonic solutions. Acta Anaesthesiol Scand. 2002;46:625-38.

Conflict of interest: none

Financial source: none

\section{Correspondence:}

Dr. Artur Udelsmann

Av. Prof. Atílio Martini, 213

13083-830 Campinas - SP BRAZIL

Phone / Fax: (55 19)3521-9560

audelsmann@yahoo.com.br

Received: October 29, 2008

Review: December 22, 2008

Accepted: January 12, 2009

\section{How to cite this article}

Udelsmann A, Bonfim MR, Silva WA, Moraes AC. Hemodynamic effects of volume replacement with saline solution and hypertonic hydroxyethyl starch in dogs. Acta Cir Bras. [serial on the Internet] 2009 Mar-Apr;24(2). Available from URL: http://www.scielo.br/acb 